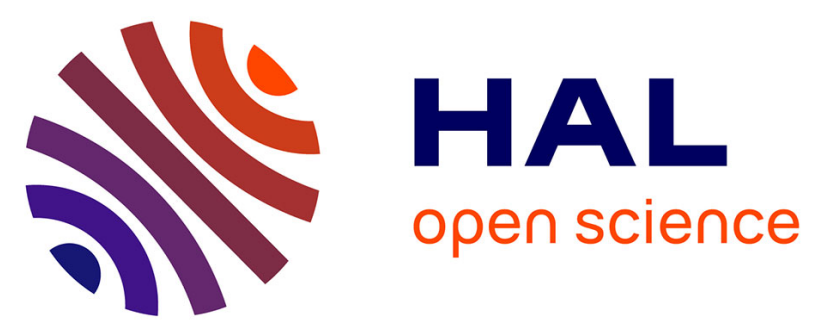

\title{
Social representations associated with men and women drivers among French adolescents and adults. Effects of perceiver's age, sex, and socioeconomic status
}

Béatrice Degraeve, Marie-Axelle Granié, Karyn Pravossoudovitch, Grégory Lo Monaco

\section{- To cite this version:}

Béatrice Degraeve, Marie-Axelle Granié, Karyn Pravossoudovitch, Grégory Lo Monaco. Social representations associated with men and women drivers among French adolescents and adults. Effects of perceiver's age, sex, and socioeconomic status. Transportation Research Part F: Traffic Psychology and Behaviour, 2015, 34, pp.1-17. 10.1016/j.trf.2015.07.019 . hal-01213503

\section{HAL Id: hal-01213503 \\ https://hal.science/hal-01213503}

Submitted on 8 Oct 2015

HAL is a multi-disciplinary open access archive for the deposit and dissemination of scientific research documents, whether they are published or not. The documents may come from teaching and research institutions in France or abroad, or from public or private research centers.
L'archive ouverte pluridisciplinaire HAL, est destinée au dépôt et à la diffusion de documents scientifiques de niveau recherche, publiés ou non, émanant des établissements d'enseignement et de recherche français ou étrangers, des laboratoires publics ou privés. 
Pour citer: Degraeve, B., Granié, M.-A., Lo Monaco, G., \& Pravossoudovitch, K. (2015). Social representations associated with men and women drivers among French adolescents and adults. Effects of perceiver's age, sex, and socioeconomic status. Transportation Research Part F: Traffic Psychology and Behaviour, 34, 1-17. doi: 10.1016/j.trf.2015.07.019

\title{
Social representations associated with men and women drivers among French adolescents and adults. Effects of perceiver's age, sex, and socioeconomic status.
}

\author{
Béatrice Degraeve ${ }^{1}$, Marie-Axelle Granié ${ }^{2}$, Karyn Pravossoudovitch ${ }^{2,3}$ \& Grégory Lo \\ Monaco $^{4}$ \\ ${ }^{1}$ Université de Nîmes, LPS EA 849, 30000 Nîmes, France \\ ${ }^{2}$ IFSTTAR-TS2-LMA, F13300, Salon de Provence, France \\ ${ }^{3}$ Aix-Marseille Université, CNRS, ISM UMR 7287, 13288 Marseille Cedex 09, France \\ ${ }^{4}$ Aix-Marseille Université, LPS EA 849, 13621 Aix en Provence, France
}

\begin{abstract}
The aim of this study was to investigate the specific contents of the social representations (SR) associated with men and women drivers and to examine the effects of the social insertions of individuals (i.e., age, sex and socio-economic status) on the content and the structure of these SR. A preliminary study with 414 French participants identified thematic content associated with men and women drivers through the method of verbal associations. Based on these themes, 833 French participants, equally distributed on the basis of age group (from 12 to 50 years-old and over), sex and socio-economic status (SES), were asked to answer a questionnaire on men $(N=422)$ or women $(N=411)$ drivers. The results show that these SR are each organized around three factors: incompetence, prudence and lack of selfcontrol for women drivers; carelessness, skills and self-control for men drivers. In-group
\end{abstract}


favoritism bias can be noted as male participants, more than female ones, rated men drivers as having self-control and women drivers as lacking self-control, whereas female participants, more than male ones, perceived men drivers as careless and women drivers as prudent. Despite this phenomenon, in all age groups, male respondents, more than female ones, seem to believe that women are not competent for driving, whereas both sexes seem to agree on men good driving skills. Among most age groups, three characteristics associated with man drivers (confidence, fastness and pleasure of driving) and four characteristics associated with female drivers (caution, civility, compliance with rules and vigilance) emerge as central in the SR. The SR associated with men drivers seem to be stable and shared across age groups, whereas the SR associated with women drivers appear more mixed, heterogeneous and unstable with age. Participants with higher SES consider female drivers as more incompetent, more nervous and less cautious than participants with lower SES and female's responses tend be closer to those provided by the male group when they are higher SES.

Key words: social representation, core-periphery analysis, social insertion, stereotypes, sex, driver. 


\section{Introduction}

There are many empirical evidences outlining sex differences in driving behaviors and accidentology. In most Western countries, men are two to three times more likely to die in a traffic accident than women (Hanna, Taylor, Sheppard, \& Laflamme, 2006; Nell, 2002; Özkan \& Lajunen, 2005). Their probability of being injured in a car accident is $25 \%$ higher than women (Evans, 1991). Studies show that men are more frequently involved in accidents related to a traffic rule violation. In France, at equal mileage, women have 2.5 times fewer points removed from their driving licenses, and are 6.2 times less convicted for offenses (Assailly, 2005). Indeed, men show a lower degree of normative motivation to comply with traffic rules (Yagil, 1998).

However, despite these objective data about accidentology, women are still considered as being poor drivers. In fact, many studies in the field of stereotypes showed that the negative stereotype against women drivers is still effective. Berger (1986) tried to understand the origin of the popular beliefs against women drivers and how a negative stereotype spread towards them in the early twentieth century. According to him, this stereotype would be linked to beliefs that they would be unable to handle stressful situations requiring rapid decision making because of their physical and emotional sensitive constitution, which would make them poor drivers. Otherwise, some studies suggest that these stereotypes are used by drivers, which may impact on driving behaviors (Davies \& Patel, 2005; Derks, Scheepers, Laar, \& Ellemers, 2011). In the framework of the stereotype threat phenomenon (Steele \& Aronson, 1995), these stereotypes provide the foundation for strong inductive inferences, which can have significant cognitive and behavioral consequences, and particularly for the driving activity. Studies thus showed that negative beliefs associated with female drivers could lead to an impairment of their driving performances (Chateignier, Chekroun, Nugier, \& Dutrévis, 2011; Félonneau \& Becker, 2011; Yeung \& von Hippel, 2008).

The study of how individuals perceive "the man and woman behind the wheel" may be useful for apprehending and understanding the various speculations and everyday discussions in this area. Moreover, it also appears to be an important aspect for studies on stereotype threat phenomenon and its implications in the context of driving. However, as far as we know, the precise content of these perceptions has not been explored in depth among adults but only among adolescents (Granié \& Papafava, 2011). 
The theory of social representations (SR) is relevant to fully apprehend these daily discussion topics, insofar as it allows revealing the content and the structural organization of such social constructs but also allows putting it into perspective with the social insertions of individuals. This theory provides a methodological framework for the study of the aspects associated with men and women drivers. SR are common sense theories used to give meaning to social objects (Moscovici, 1988, 2008). These lay theories circulate through society as knowledge of common sense to explain, make sense, and understand the environment. Thus, SR are a form of shared social knowledge. In this sense, the SR of a social group corresponds to the way individuals perceive this group, and is composed of all the information and beliefs that individuals socially produce and share (Moscovici, 2008).

Since the work initiated by Moscovici on SR, two approaches have focused on their organization. Firstly, in the framework of the structural model of the SR, the "central core theory" was developed by Abric (1993, 2001; see Rateau, Moliner, Guimelli, \& Abric, 2011, for a review) to investigate the internal hierarchy of SR. This approach aims at demonstrating how are structured the elements constituting a representation. This theory assumes that any representation is organized around and structured by a central core, which is composed of a few elements (i.e., opinions, beliefs, knowledge) that are subject to a consensus among the individuals who share this representation and are insensitive to context variations (Abric, 2001; Flament, 1995; Lo Monaco, Lheureux, \& Halimi-Falkowicz, 2008; Rateau et al., 2011; Wagner, Valencia, \& Elejabarrieta, 1996). Otherwise, various elements are also related to the representation but are not part of the central core. These "peripheral elements" allow some flexibility in the representation and reflect the individual appropriation and the context in which they are actualized.

Secondly, according to Doise $(1986,1990)$ and the sociodynamic model, representations are structured by common "organizing principles", from which will occur interindividual differences. These variations in the position-taking about such or such object are regulated by the social positions of the individuals, their experiences or their integration in a context or a given social situation. For Doise, Clémence and Lorenzi-Cioldi (1993), the study of the SR is not limited to their consensual properties but shall include the socially regulated interindividual variations derived from the representational field (i.e., taking into account the variations between individuals and groups in the organization and the dynamics of a social representation). These individual variations are considered as systematic fluctuations in the weight (and/or in the degree of importance) that individuals or groups give to the various dimensions underlying the representational structure. Contrary to the central core theory, the 
analysis of the representational structure consists in the identification of the principles that organize individual differences. Usually within the framework of the study of social representations, the organizing principles are identified with multidimensional data analyses. Moreover, in line with Bourdieu (1990), it aims at studying the social regulations of the various position-taking, therefore the social anchoring of the ways to represent the object. In this sense, considering the social anchoring consists in analyzing the effects of social insertions on a particular SR. According to the principle of structural homology (Bourdieu, 1990), there are correspondences between cognitive structures and social insertions. Thus, it is possible to observe links in the social field between the occupied social position and the individuals' ways to think and to position themselves about, for examples, an object, a debate, the adoption or not of a social practice, etc.

In this context, these two different approaches have been developed to account for SR. Indeed, one can distinguish the structural model, which is based on the concept of consensus, from the sociodynamic model, which focuses, on its part, on socially regulated interindividual variations. In line with these two approaches of SR, a number of studies (e.g., Lo Monaco, Piermattéo, Guimelli, \& Abric, 2012; Moliner, 1995; Moliner \& Tafani, 1997; Rateau, 2004; Tafani, Bellon, \& Apostolidis, 2002) have tried to articulate them. Indeed, the objective was to take into account both the consensus and the inter-individual variations. In order to study the effect of social regulation on the structure of SR, recent studies articulated the use of methodologies designed to explore the structure of the SR according to the central core theory (Moliner, 2002) and multidimensional data analyses more related to the sociodynamic model (Doise et al., 1993). Proceeding in this way allows to identify the effect of social insertions relative to an object and to study the structure of SR among subgroups (Lo Monaco et al., 2012).

In this framework, some studies already shown how gender asymmetries (e.g., LorenziCioldi, 1997; Lo Monaco et al., 2012) and economic and cultural asymmetries (e.g., Flament, 1996; Lo Monaco et al., 2012; Tafani \& Bellon, 2001; Viaud, 2000) could have an impact on some SR. However, few studies considered the effect of the age. In the framework of intergroup relation studies, Dafflon (1999) shows that the perceived homogeneity of the outgroup varies according to some affiliation such as age, which can generate asymmetrical relations. It can be hypothesized that, due to the effects of socialization and the gradual internalization of asymmetries in the social structure, the perception of the out-group changes with age, that can influence the structure of SR related to social groups (Dafflon, 1999). 
Despite its fruitful use to understand the social objects, the theoretical framework of the SR has been rarely mobilized in the field of transportation. Only one study from Pianelli, Abric and Saad (2010) analyzed the SR of traffic speed, of speed limitation and of an intelligent speed limitation system, and the effect of social anchoring on these SR through multidimensional analyses. To the best of our knowledge, no studies have investigated the content and structure of the SR associated with men and women drivers, nor the effect of perceiver's age, sex, and socioeconomic status (SES) on these SR.

In this context, this research attempts to analyze the specific content of the social representation of "the man and woman behind the wheel", specifying their different modalities of social anchoring. Indeed, the SR theory is susceptible to clarify this issue, insofar as it can determine the content of a representation, and allows putting this content in perspective with social insertion (Doise, 1993). More specifically, concerning the social regulations, the present study proposes to examine how the importance attributed to these contents and the structural status of the elements composing the SR may vary depending on the social insertion of individuals using several socio-demographic variables such as age, sex and SES. The methodological framework provided by the structural approach to SR seems appropriate and relevant to bring out the content of these social constructs as well as its structure.

\section{Methodological perspectives}

In order to explore the SR associated with men and women drivers and the structural status of the characteristics associated with these SR, according to social insertions, a preliminary study was conducted to identify the specific content of the SR.

Method used for this preliminary study was a verbal association procedure. This method is particularly effective for identifying the specific content of social representations (Abric, 2003), which is the case of the present research. Many studies used the method of verbal associations to reveal various representational contents (Dany, Urdapilleta, \& Lo Monaco, 2015; Gaymard, 2006; Lo Monaco \& Guimelli, 2011; Mouret, Lo Monaco, Urdapilleta, \& Parr, 2013; Slovic, Flynn, \& Jayman, 1991; Wagner et al., 1996).

Data collection was conducted on a convenience basis, in some cities in southeastern France, such as Marseilles and Salon-de-Provence. French-speaking participants $(N=414)$ were 
asked to associate "5 words or expressions that came to mind to describe a man (or a woman) driver". Two hundred and three participants were asked to produce associations from the inductor "man driver" and 211 participants were asked to produce associations from the inductor "woman driver". The sample was balanced on sex, age and SES to ensure data comparability with the main study.

The thematic analysis conducted on the SR of "the man driver" allowed to identify 17 topics more or less frequently mentioned by participants: disrespectful, impatient, fast, dangerous, do not comply with the traffic law, manly, show-off, dexterous, careful, confident, pleasure of driving, technical skills, inattentive, civic, incompetent, natural facilities, calm. The thematic analysis conducted on the SR of the "woman driver" allowed to identify 17 topics: careful, dangerous, inattentive, lack of technical skills, slow, clumsy, comply with the traffic law, vigilant, civic, lack of confidence, disrespectful, calm, impatient, transgression of the rules, not made for driving, mastery of the vehicle, functional aspects of the driving. These characteristics and their frequencies of occurrence in the sample are presented in Appendix A.

The topics mentioned by participants became the items of the questionnaire of the present study, which were used to test the effects of the social anchoring on the content and structure of these SR.

\subsection{Social representations associated with men and women drivers}

The first objective of the present study was to assess the importance attributed to the different characteristics associated with man or woman driver. The list of topics associated with the SR of the man or woman driver was submitted to the participants. For each characteristic, they were asked to evaluate their respective importance by indicating the extent to which it corresponds to their idea of the man or woman driver. Participants positioned themselves on a 10-point scale (from (1) = "no, not at all" to (10) = "yes, absolutely").

\subsection{Structural status of characteristics associated with men and women drivers}

The second objective was to explore the structure of these SR in order to identify the essential or central character of the elements that compose the core of the SR of the man or woman driver.

The list of topics associated with the SR of the man or woman driver was resubmitted to the participants. Instructions delivered to participants were the following: "in your opinion, are 
men (or women) drivers always, in all cases...?”. In accordance with Lo Monaco et al. (2008), for each item, four categories of answers were proposed (i.e., $1=$ definitely not, $2=$ rather not, 3 = rather yes, 4 = definitely yes).

To make a distinction between the components of the representational field, a structural diagnostic test was used to proceed to a systematic identification of the central vs. peripheral elements. The "test of context independence (TCI)" (Lo Monaco et al., 2008) is based on the context-insensitivity property of the central elements of a SR. Indeed, this test assumes that central elements have a trans-situational property conferring them an insensitivity to the immediate context, whereas the peripheral elements are characterized by a lower insensitivity to the context variations than central ones (Abric, 1993, 2001; Flament, 1995; Wagner et al., 1996).

Lastly, the last part of the questionnaire consisted of identification questions. In order to test the effects of the social variables on the structures of the SR, sex, age and SES were asked. Two other identification variables were added to control their effects on the SR (validation of driving license and year of validation).

\subsection{Sample and procedure}

In the main study, 833 French-speaking participants answered either the questionnaire on women $(N=411)$ or the questionnaire on men $(N=422)$ drivers. The population was divided into subgroups based on age, sex and SES (Table 1). A junior-high school and a high school were solicited in southeastern France, in order to collect data on participants aged between 12 and 15 years and between 16 and 18 years. Concerning adult participants, data collection was conducted in some cities in southeastern France, such as Marseilles and in a southeastern France hospital where we were allowed to interview people in the waiting rooms.

The socio-economic status (SES) was obtained by asking participants to which occupational category they belong and by classify them according to the grid of occupational categories of the French National Institute of Statistics and Economic Studies (e.g., Desrosières \& Thévenot, 2002; Tafani, Haguel, \& Ménager, 2007), in order to obtain a balanced sample between higher SES (Entrepreneurs, liberal professions, intellectual professions) and lower SES (intermediate professions, employees or workers). Students or high school students were asked about the occupational status of their parents. 
Among the respondents on the "woman driver" questionnaire, $241(58.6 \%)$ had a driver's license. This license was obtained on average during the year 1990. Concerning respondents on the "man driver" questionnaire, $250(59.2 \%)$ had a driver's license. This license was obtained on average during the year 1991.

Table 1. Distribution of the sample according to age, sex and socio-economic status (SES).

\begin{tabular}{|c|c|c|c|c|c|c|c|c|c|}
\hline \multirow[b]{3}{*}{ Age } & \multicolumn{4}{|c|}{ Man driver } & \multicolumn{4}{|c|}{ Women driver } & \\
\hline & \multicolumn{2}{|c|}{$\begin{array}{c}\text { Male } \\
\text { participants }\end{array}$} & \multicolumn{2}{|c|}{$\begin{array}{c}\text { Female } \\
\text { participants }\end{array}$} & \multicolumn{2}{|c|}{$\begin{array}{c}\text { Male } \\
\text { participants }\end{array}$} & \multicolumn{2}{|c|}{$\begin{array}{c}\text { Female } \\
\text { participants }\end{array}$} & \multirow[b]{2}{*}{ Tota } \\
\hline & SES+ & SES- & SES+ & SES- & SES+ & SES- & SES+ & SES- & \\
\hline $12-15$ & 22 & 22 & 15 & 23 & 19 & 20 & 16 & 20 & 157 \\
\hline $16-18$ & 19 & 17 & 20 & 23 & 17 & 21 & 22 & 24 & 163 \\
\hline $19-29$ & 20 & 23 & 21 & 23 & 19 & 21 & 21 & 20 & 168 \\
\hline $30-49$ & 21 & 25 & 20 & 24 & 21 & 20 & 21 & 23 & 175 \\
\hline 50 and over & 20 & 22 & 20 & 22 & 22 & 21 & 20 & 23 & 170 \\
\hline Total & 102 & 109 & 96 & 115 & 98 & 103 & 100 & 110 & 833 \\
\hline
\end{tabular}

Note. SES+ refers to higher SES, SES- refers to lower SES.

\section{Results}

\subsection{Factors organizing the SR on men and women drivers}

In order to extract the factors organizing the representational field, data on the importance attributed to the different characteristics associated with man or woman driver were analyzed through a Principal Component Analysis (PCA) with Oblimin rotation. Oblimin rotations were preferred since a link was assumed between the different dimensions organizing the SR (Fabrigar, Wegener, MacCallum, \& Strahan, 1999). The selected factors are those with eigenvalues higher than 1, according to Kaiser's (1960) criterion. A cut-off point of .40 was used for item loading values. Items with loading values $>.39$ on two factorial axes or more were excluded. This analysis allowed to identify 3 factors that explained $61.73 \%$ of the variance for the "man driver" and 3 factors that explain $53.75 \%$ of the variance for the "woman driver".

For men drivers (see Table 2), on Factor 1 (35.32\% of explained variance) loaded characteristics related to the incompetence, inattention, non-compliance with the traffic laws, danger and disrespect, in this case characteristics related to the "carelessness" of men drivers 
( $\alpha=.83)$. Factor 2 (16.40\% of explained variance), which included the technical skills, the pleasure of driving, the self-confidence and the speed, can be interpreted as related to the “driving skills" possessed by men $(\alpha=.66)$. Factor 3 (10.01\% of explained variance) on which loaded the elements "calm", "civic", "careful" and "impatient" (with opposite saturation for this last item, thus making reference to patience; $\alpha=.78$ ), reflected "self controlled" relations to others and more specifically a patient driving style (Taubman-BenAri, Mikulincer, \& Gillath, 2004). Four items ("manly", "show-off”, "natural facilities" and "dexterous") which loaded on two factorial axes or more were excluded, resulting in a threefactor solution containing 13 items.

Table 2. Saturation of the items on the three factors resulting from the Principal Component Analysis (PCA) with Oblimin rotation of the different characteristics associated with the man driver.

\begin{tabular}{|c|c|c|c|c|}
\hline & $\begin{array}{l}\text { Mean } \\
\text { (SD) }\end{array}$ & $\begin{array}{c}\text { Factor } 1 \\
\text { Carelessness }\end{array}$ & $\begin{array}{c}\text { Factor } 2 \\
\text { Driving skills }\end{array}$ & $\begin{array}{c}\text { Factor } 3 \\
\text { Self control }\end{array}$ \\
\hline Incompetent & $4.03(2.11)$ & .894 & & \\
\hline Inattentive & $4.82(2.02)$ & .806 & & \\
\hline Do not comply with the traffic law & $5.70(2.44)$ & .711 & & \\
\hline Dangerous & $5.75(2.36)$ & .624 & & \\
\hline Disrespectful & $5.57(2.40)$ & .547 & & \\
\hline Technical skills & $7.16(1.95)$ & & .741 & \\
\hline Pleasure of driving & $7.88(1.92)$ & & .736 & \\
\hline Confident & $7.32(1.74)$ & & .662 & \\
\hline Fast & $7.14(1.84)$ & & .621 & \\
\hline Calm & $4.22(2.11)$ & & & .940 \\
\hline Civic & $4.36(2.17)$ & & & .889 \\
\hline Careful, cautious & $5.66(1.98)$ & & & .553 \\
\hline Impatient & $4.43(2.19)$ & & & -.404 \\
\hline Eigenvalues & & 4.59 & 2.13 & 1.30 \\
\hline Cronbach alpha & & .83 & .66 & .78 \\
\hline Percentage of explained variance & & $35.32 \%$ & $16.40 \%$ & $10.01 \%$ \\
\hline
\end{tabular}

For women drivers (see Table 3), on Factor 1 (33.62\% of explained variance) loaded aspects related to the clumsiness, slowness, lack of technical skills and confidence, inattention, danger, "not made for driving" aspects, and mastery of the vehicle (with a reverse saturation), in this case characteristics relating to the "incompetence" of women drivers $(\alpha=.81)$. Factor 2 (12.54\% of explained variance), which included the prudence, the compliance with the traffic laws, and the vigilance, can be interpreted as related to the "prudence" of female drivers $(\alpha=$ .77). Finally, Factor 3 (7.59\% of explained variance) included the impatience, calm, civility (with opposite saturation for both items, thus making reference to the lack of civility and 
calm) and disrespect, which referred to the interaction with other road users, and more specifically to a "lack of self control" $(\alpha=.66)$.

Two items ("the functional aspects of the conduct" and "transgression of the rules") which loaded on two factorial axes or more were excluded, resulting in a three-factor solution containing 15 items.

Table 3. Saturation of the items on the three factors resulting from the Principal Component Analysis (PCA) with oblimin rotation of the different characteristics associated with the woman driver.

\begin{tabular}{|c|c|c|c|c|}
\hline & Mean (SD) & $\begin{array}{c}\text { Factor } 1 \\
\text { Incompetence }\end{array}$ & $\begin{array}{l}\text { Factor } 2 \\
\text { Prudence }\end{array}$ & $\begin{array}{c}\text { Factor } 3 \\
\text { Lack of self control }\end{array}$ \\
\hline Clumsy & $4.18(2.26)$ & .787 & & \\
\hline Slow & $5.23(2.49)$ & .739 & & \\
\hline Lack of technical skills & $5.08(2.68)$ & .667 & & \\
\hline Lack of confidence & $4.59(3.53)$ & .626 & & \\
\hline Inattentive & $4.78(2.45)$ & .599 & & \\
\hline Dangerous & $4.10(2.44)$ & .587 & & \\
\hline Not made to drive & $2.60(2.38)$ & 479 & & \\
\hline Mastery of the vehicle & $6.34(2.30)$ & -.47 & & \\
\hline Careful, cautious & $7.19(2.14)$ & & .822 & \\
\hline Comply with the traffic law & $7.23(2.03)$ & & .778 & \\
\hline Vigilant & $6.73(2.10)$ & & .757 & \\
\hline Impatient & $5.35(2.18)$ & & & .824 \\
\hline Calm & $5.93(2.07)$ & & & -.581 \\
\hline Civic & $6.54(2.14)$ & & & -.535 \\
\hline Disrespectful & $3.38(2.25)$ & & & .533 \\
\hline Eigenvalues & & 5.04 & 1.88 & 1.13 \\
\hline Cronbach alpha & & .81 & .77 & .66 \\
\hline Percentage of explained variance & & $33.62 \%$ & $12.54 \%$ & $7.59 \%$ \\
\hline
\end{tabular}

On the basis of the factors highlighted by the PCA, a score of items saturating on each of these factors was computed and used as composite scores in the following analyses. Items that loaded with opposite saturation (i.e., Impatient, Mastery of the vehicle, Calm and Civic) were reversed to compute these composite scores.

\subsection{Effect of perceiver's age, sex and socioeconomic status on elements associated with men} drivers

Scores of individuals on the three factors associated with men drivers generated from the Principal Component Analysis were subjected to a series of ANOVAs in order to test the effects of the socio-demographic variables (sex, age and SES) on the characteristics attributed to the man driver. A first series of ANOVAs was conducted on the whole sample and effects 
of sex and SES were then tested for each age group separately. Bonferroni post hoc tests were used to report the significant differences between age groups when the ANOVA shown a significant effect of age. Mean scores on each factor according to gender, age and SES groups are summed up in Table 4. All the effects of socio-demographic variables (statistical criteria and significance) on the importance attributed to organizing principles of the SR of men drivers, for the whole sample and analyzed by age group, are summed up in Table 5.

Concerning Factor 1 (i.e., Carelessness), significant main effects were observed for perceiver's sex and age on the whole sample. As seen in table 4, women attributed greater importance to this factor than men. The Bonferroni post-hoc test showed that the 12-15 attributed lower importance to this factor $(p<.05)$ than the 19-29.

Concerning Factor 2 (i.e., Driving skills), a significant main effect of perceiver's age was observed on the whole sample. The Bonferroni post-hoc test showed that the 16-18 attributed greater importance to this factor $(p<.05)$ than the 50 years and over. Concerning the 19-29 years group, an interaction effect between sex and SES was observed. The sex difference was greater for the lower SES group than for the higher SES group, as shown in table 4. For the 30-49 years group, a main effect of sex was observed. In this age group, female respondents scored men driving skills higher than male did.

Concerning Factor 3 (i.e., Self control), a significant main effect of perceiver's sex was observed on the whole sample. Men attributed greater importance to this factor than women. An interaction effect of sex and SES was observed among participants aged 50 and over, where the sex difference was greater for the lower SES group than for the higher SES group, as shown in table 4 . 
2 Table 4. Mean composite scores on each factor according to age, sex and SES ${ }^{1}$.

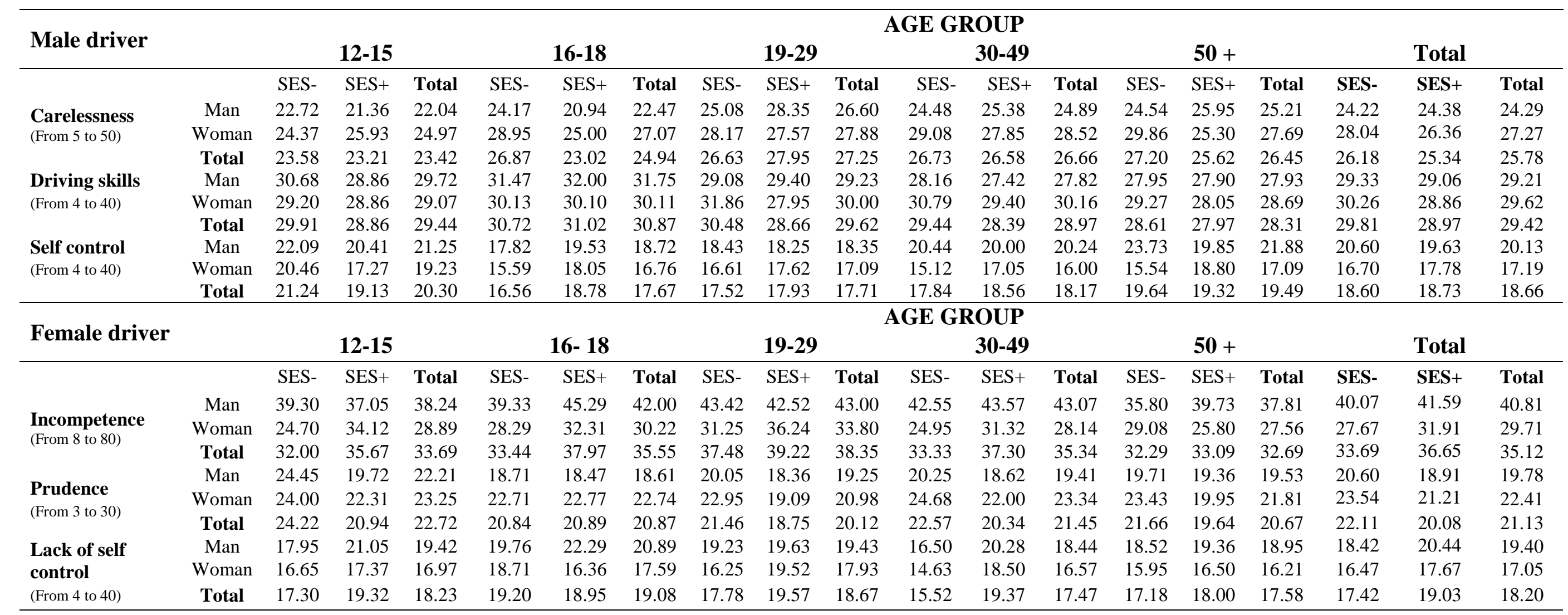

\footnotetext{
${ }^{1}$ Standard deviations have not been reported for the sake of clarity but are available upon request from the corresponding author.
} 
3.3. Effect of perceiver's age, sex and socioeconomic status on elements associated with women drivers

6 Scores of individuals on the three factors associated with women drivers generated from the

7 PCA were subjected to a series of ANOVAs in order to test the effects of the sociodemographic variables (age, sex and SES) on the characteristics attributed to the woman driver. A first series of ANOVAs was conducted on the whole sample and effects of sex and SES were then tested for each age group separately. Bonferroni post hoc tests were used to report the significant differences between age groups when the ANOVA shown a significant effect of age. Mean scores on each factor according to sex, age and SES groups are summed up in Table 4. All the effects of socio-demographic variables (statistical criteria and significance) on the importance attributed to organizing principles of the SR of women drivers, for the whole sample and analyzed by age group, are summed up in Table 5.

Concerning Factor 1 (i.e., Incompetence), significant main effects were observed for perceiver's sex, age and SES on the whole sample. As shown in table 4, women's incompetence was more pronounced among men and higher SES respondents than among women and lower SES respondents. The Bonferroni post-hoc test $(p<.05)$ showed the group aged 19-29 attributed a greater importance to this factor than the group aged 50 and over.

Concerning Factor 2 (i.e., Prudence), significant main effects of perceiver's sex, age and SES can be observed on the whole sample. As shown in table 4, women and lower SES respondents attributed greater importance to this factor than men and higher SES respondents. The Bonferroni post-hoc test $(p<.05)$ showed respondents between 12 and 15 attributed greater importance to this factor than other age groups.

Concerning Factor 3 (i.e., Lack of self control), significant main effects of perceiver's sex and SES were observed on the whole sample, where men and higher SES respondents attributed greater importance to this factor than women and lower SES respondents. 
31 Table 5. Effects of socio-demographic variables on the importance attributed to organizing principles of the two SR, for the whole sample and by age groups.

\begin{tabular}{|c|c|c|c|c|c|c|c|}
\hline & & \multicolumn{3}{|c|}{ Men drivers } & \multicolumn{3}{|c|}{ Women drivers } \\
\hline & & $\begin{array}{c}\mathrm{F} 1 \\
\text { Carelessness }\end{array}$ & $\begin{array}{c}\mathrm{F} 2 \\
\text { Driving skills }\end{array}$ & $\begin{array}{c}\text { F3 } \\
\text { Self control }\end{array}$ & $\begin{array}{c}\mathrm{F} 1 \\
\text { Incompetence }\end{array}$ & $\begin{array}{c}\text { F2 } \\
\text { Prudence }\end{array}$ & $\begin{array}{c}\text { F3 } \\
\text { Lack of self control }\end{array}$ \\
\hline \multicolumn{8}{|c|}{ Whole sample } \\
\hline \multicolumn{2}{|l|}{ Sex } & $F(1,402)=11.72^{* * *}, \eta_{\mathrm{p}}^{2}=.03$ & - & $F(1,402)=21.01^{* * *}, \eta_{\mathrm{p}}^{2}=.05$ & $F(1,400)=82.24^{* * *}, \eta_{\mathrm{p}}^{2}=.17$ & $F(1,400)=28.03^{* * *}, \eta_{\mathrm{p}}^{2}=.06$ & $F(1,400)=15.93^{* * *}, \eta_{\mathrm{p}}^{2}=.04$ \\
\hline \multicolumn{2}{|l|}{ Age } & $F(4,402)=2.55^{*}, \eta^{2}=.02$ & $F(4,402)=2.73^{*}, \eta_{\mathrm{p}}^{2}=.02$ & - & $F(4,400)=2.70^{*}, \eta^{2}{ }_{p}=.02$ & $F(4,400)=3.12^{*}, \eta^{2}=.03$ & - \\
\hline \multicolumn{2}{|l|}{ SES } & - & - & - & $F(1,400)=4.87^{*}, \eta_{\mathrm{p}}^{2}=.01$ & $F(1,400)=15.97^{* * *}, \eta_{\mathrm{p}}^{2}=.04$ & $F(1,400)=7.25^{* *}, \eta_{\mathrm{p}}^{2}=.02$ \\
\hline \multicolumn{2}{|c|}{ Sex $X$ age } & - & - & - & - & - & - \\
\hline \multicolumn{2}{|c|}{ Sex X SES } & - & - & - & - & - & - \\
\hline \multicolumn{2}{|c|}{ Age X SES } & - & - & - & - & - & - \\
\hline \multicolumn{2}{|c|}{ Sex X Age X SES } & - & - & - & - & - & - \\
\hline \multicolumn{8}{|c|}{ By age group } \\
\hline \multirow[t]{3}{*}{$12-15$} & Sex & - & - & - & $F(1,70)=7.91^{* *}, \eta_{\mathrm{p}}^{2}=.10$ & - & - \\
\hline & SES & - & - & - & - & $F(1,70)=6.99^{* *}, \eta_{\mathrm{p}}^{2}=.09$ & - \\
\hline & Sex X SES & - & - & - & - & - & - \\
\hline \multirow[t]{3}{*}{ 16-18 } & Sex & $F(1,74)=4.79^{*}, \eta_{\mathrm{p}}^{2}=.06$ & - & - & $F(1,80)=22.82^{* * *}, \eta_{\mathrm{p}}^{2}=.22$ & $F(1,80)=15.93^{* * *}, \eta_{\mathrm{p}}^{2}=.16$ & $F(1,80)=9.12^{* *}, \eta_{\mathrm{p}}^{2}=.10$ \\
\hline & SES & - & - & - & $F(1,80)=3.94^{*}, \eta_{\mathrm{p}}^{2}=.04$ & - & - \\
\hline & Sex X SES & - & - & - & - & - & $F(1,80)=4.44^{*}, \eta_{\mathrm{p}}^{2}=.05$ \\
\hline \multirow[t]{3}{*}{$19-29$} & Sex & - & - & - & $F(1,77)=9.88^{* * *}, \eta_{p}^{2}=.11$ & - & - \\
\hline & SES & - & - & - & - & $F(1,77)=7.42^{* *}, \eta_{\mathrm{p}}^{2}=.08$ & - \\
\hline & Sex X SES & - & $F(1,83)=4.61^{*}, \eta_{\mathrm{p}}^{2}=.05$ & - & - & - & - \\
\hline \multirow[t]{3}{*}{$30-49$} & Sex & - & $F(1,86)=5.27^{*}, \eta_{\mathrm{p}}^{2}=.05$ & $F(1,86)=8.12^{* *}, \eta_{\mathrm{p}}^{2}=.08$ & $F(1,81)=29.92^{* * *}, \eta_{\mathrm{p}}^{2}=.27$ & $F(1,81)=20.31^{* * * *}, \eta_{\mathrm{p}}^{2}=.21$ & - \\
\hline & SES & - & - & - & - & $F(1,81)=6.18^{* *}, \eta_{\mathrm{p}}^{2}=.07$ & $F(1,81)=8.50^{* *}, \eta_{\mathrm{p}}^{2}=.09$ \\
\hline & Sex X SES & - & - & - & - & - & - \\
\hline \multirow[t]{3}{*}{$50+$} & Sex & - & - & $F(1,80)=13.91^{* * *}, \eta_{\mathrm{p}}^{2}=.14$ & $F(1,82)=19.39^{* * *}, \eta_{\mathrm{p}}^{2}=.19$ & - & $F(1,82)=4.42^{*}, \eta_{\mathrm{p}}^{2}=.05$ \\
\hline & SES & - & - & - & - & - & - \\
\hline & Sex X SES & - & - & $F(1,80)=8.30^{* *}, \eta_{\mathrm{p}}^{2}=.09$ & - & - & - \\
\hline
\end{tabular}

Note. ${ }^{*} p<.05 ;{ }^{* *} p<.01 ;{ }^{* * *} p<.001$. 


\subsection{Central elements}

The aim of the study was also to highlight the central/peripheral structure of the representations studied. In order to realize a diagnosis of centrality, the "test of context independence (TCI)" (Lo Monaco et al., 2008) was used (see section 2.2). As central elements are considered to be independent of the immediate context, an item is considered as central if it designates always, in any case a characteristic of the given SR (i.e., by answering affirmatively to the TCI). In line with this method, a characteristic is considered central if it gives rise to an affirmation rate that does not significantly differ from $100 \%$ (i.e., using the Dmax Kolmogorov-Smirnov test: Abric, 2003; Kanji, 2006; Lo Monaco et al., 2008; Moliner, Rateau, \& Cohen-Scali, 2002). In accordance with Lo Monaco et al. (2008), the affirmation rate was calculated by combining the answers "rather yes" $(=3)$ and "definitely yes" $(=4)$. Given the number of participants, an affirmation frequency was considered as close to 100, at a significance level of $p<.05$, if it exceeded the threshold calculated by the test (for example, if the affirmation frequency was 79.26 or more for the men aged 50 and over about women drivers). Since the number of participants varied depending on the condition, a corresponding threshold was calculated for each group in order to determine the structural status (i.e., central or peripheral) of each element. Table 6 and 7 gives the affirmation frequencies observed in each group.

\section{Insert Table 6 and 7 here}

Table 6 shows that, for the man driver, three elements emerged as central in most age groups: confidence, fastness and pleasure of driving. These elements all refer to the factor related to the "driving skills" possessed by men (Factor 2 of the PCA).

Concerning the representation of the woman driver, table 7 shows that four elements emerge as central in most groups (and more specifically among adults for some of them): caution, civility, compliance with rules and vigilance. Three of these elements (caution, vigilance and compliance) are connected to the "prudence" attributed to women (Factor 2 of the PCA) and the fourth (civility) is related to the relationship with other users in its positive aspect (Factor 3 of the PCA). 
63 Table 6. Central elements identified on the basis of the Kolmogorov-Smirnov test for men drivers (in \%).

\begin{tabular}{|c|c|c|c|c|c|c|c|c|c|c|c|c|c|c|c|c|}
\hline \multirow[b]{2}{*}{ Factor } & & \multicolumn{3}{|c|}{$12-15$} & \multicolumn{3}{|c|}{$16-18$} & \multicolumn{3}{|c|}{$19-29$} & \multicolumn{3}{|c|}{$30-49$} & \multicolumn{3}{|c|}{$50+$} \\
\hline & & Male & Female & Total & Male & Female & Total & Male & Female & Total & Male & Female & Total & Male & Female & Total \\
\hline \multirow[t]{5}{*}{ Carelessness } & $\begin{array}{l}\text { Do not comply with } \\
\text { the traffic law }\end{array}$ & 44.2 & 35.1 & 40.0 & 60.0 & 57.1 & 58.4 & 83.7* & 75.0 & 79.3 & 69.6 & 68.2 & 68.9 & 53.7 & 81.0* & 67.5 \\
\hline & Dangerous & 48.8 & 40.5 & 45.0 & 52.8 & 52.4 & 52.6 & 60.5 & 54.5 & 57.5 & 57.8 & 36.4 & 47.2 & 31.0 & 42.9 & 36.9 \\
\hline & Disrespectful & 20.9 & 26.3 & 23.5 & 41.7 & 42.9 & 42.3 & 53.5 & 59.1 & 56.3 & 65.2 & 67.4 & 66.3 & 57.1 & 69.0 & 63.1 \\
\hline & Incompetent & 14.0 & 16.2 & 15.0 & 16.7 & 21.4 & 19.2 & 20.9 & 15.9 & 18.4 & 32.6 & 22.7 & 27.8 & 29.3 & 35.7 & 32.5 \\
\hline & Inattentive & 23.3 & 31.6 & 27.2 & 27.8 & 41.5 & 35.1 & 48.8 & 27.3 & 37.9 & 41.3 & 36.4 & 38.9 & 38.1 & 41.5 & 39.8 \\
\hline \multirow[t]{4}{*}{ Driving skills } & Confident & $88.4 *$ & $92.1 *$ & $90.1 *$ & 88.9* & $100 *$ & $94.9 *$ & $90.5 *$ & $93.2 *$ & 91.9* & 93.5* & $97.7 *$ & $95.6 *$ & 88.1* & $97.6^{*}$ & 92.9* \\
\hline & Fast & $88.4 *$ & 92.1* & $90.1^{*}$ & $97.2 *$ & $95.2 *$ & $96.2 *$ & $88.4^{*}$ & 93.2* & $90.8^{*}$ & 89.1* & $93.2 *$ & 91.1* & 82.9* & 92.9* & 88.0* \\
\hline & Pleasure of driving & 74.4 & $84.2 *$ & 79.0 & $91.7 *$ & $88.1 *$ & $89.7 *$ & $90.7^{*}$ & 90.9* & $90.8^{*}$ & $93.5 *$ & $90.9 *$ & $92.2 *$ & $83.3 *$ & $90.5 *$ & $86.9 *$ \\
\hline & Technical skills & 83.3* & $86.5 *$ & 84.8* & 75.0 & $83.3 *$ & 79.5 & 76.7 & $79.5 *$ & 78.2 & 76.1 & 69.8 & 73.0 & 68.3 & 81.0* & 74.7 \\
\hline \multirow[t]{4}{*}{ Self control } & Calm & 26.2 & 32.4 & 29.1 & 22.2 & 26.2 & 24.4 & 23.3 & 13.6 & 18.4 & 28.3 & 13.6 & 21.1 & 42.9 & 19.0 & 31.0 \\
\hline & Careful, cautious & 71.4 & 57.9 & 65.0 & 38.9 & 50.0 & 44.9 & 30.2 & 38.6 & 34.5 & 43.5 & 44.2 & 43.8 & 57.1 & 35.7 & 46.4 \\
\hline & Civic & 63.4 & 64.9 & 64.1 & 33.3 & 21.4 & 26.9 & 23.8 & 20.5 & 22.1 & 26.1 & 15.9 & 21.1 & 42.9 & 23.8 & 33.3 \\
\hline & Impatient & 62.8 & 76.3 & 69.1 & 75.0 & $82.9 *$ & 79.2 & $86.0 *$ & $88.6 *$ & $87.4^{*}$ & 78.3 & 84.1* & 81.1 & 71.4 & $92.7 *$ & 81.9 \\
\hline
\end{tabular}


66 Table 7. Central elements identified on the basis of the Kolmogorov-Smirnov test for women drivers (in \%).

\begin{tabular}{|c|c|c|c|c|c|c|c|c|c|c|c|c|c|c|c|c|}
\hline \multirow[b]{2}{*}{ Factor } & & \multicolumn{3}{|c|}{$12-15$} & \multicolumn{3}{|c|}{16 - 18} & \multicolumn{3}{|c|}{$19-29$} & \multicolumn{3}{|c|}{$30-49$} & \multicolumn{3}{|c|}{$50+$} \\
\hline & & Male & Female & Total & Male & Female & Total & Male & Female & Total & Male & Female & Total & Male & Female & Total \\
\hline \multirow{8}{*}{$\begin{array}{l}\text { Incom- } \\
\text { petence }\end{array}$} & Clumsy & 31.3 & 31.4 & 31.3 & 44.1 & 19.6 & 30.0 & 57.5 & 31.7 & 44.4 & 48.8 & 20.5 & 34.1 & 35.7 & 4.8 & 20.2 \\
\hline & Dangerous & 20.6 & 9.1 & 14.9 & 32.4 & 6.5 & 17.5 & 37.5 & 14.6 & 25.9 & 22.0 & 6.8 & 14.1 & 17.1 & 4.7 & 10.7 \\
\hline & Inattentive & 36.4 & 25.7 & 30.9 & 45.5 & 15.2 & 27.8 & 45.0 & 31.7 & 38.3 & 56.1 & 25.0 & 40.0 & 45.2 & 16.3 & 30.6 \\
\hline & Lack of confidence & 53.1 & 34.3 & 43.3 & 55.9 & 22.2 & 36.7 & 67.1 & 36.6 & 50.0 & 48.8 & 13.6 & 30.6 & 35.7 & 14.0 & 24.7 \\
\hline & $\begin{array}{l}\text { Lack of technical } \\
\text { skills }\end{array}$ & 43.8 & 18.2 & 30.8 & 38.2 & 17.8 & 26.6 & 52.5 & 26.8 & 39.5 & 46.3 & 34.1 & 40.0 & 57.1 & 46.5 & 51.8 \\
\hline & $\begin{array}{l}\text { Mastery of the } \\
\text { vehicle }\end{array}$ & 68.8 & $80.0 *$ & 74.6 & 50.0 & $87.0 *$ & 71.3 & 57.5 & 70.7 & 64.2 & 65.9 & $90.9 *$ & 78.8 & 73.8 & $86.8 *$ & 80.0 \\
\hline & $\begin{array}{l}\text { Not made for } \\
\text { driving }\end{array}$ & 15.6 & 14.3 & 14.9 & 17.6 & 2.2 & 8.8 & 20.0 & 7.3 & 13.6 & 7.3 & 13.6 & 10.6 & 19.5 & 4.7 & 11.9 \\
\hline & Slow & 48.5 & 37.1 & 42.6 & 58.8 & 32.6 & 43.8 & 67.5 & 46.3 & 56.8 & 63.4 & 25.0 & 43.5 & 59.5 & 28.6 & 44.0 \\
\hline \multirow[t]{3}{*}{ Prudence } & Careful, cautious & 71.9 & 93.9* & 83.1 & 58.8 & $91.3^{*}$ & 77.5 & $82.5 *$ & 92.7* & $87.7 *$ & 87.8* & $95.5 *$ & $91.8 *$ & $90.5 *$ & 92.9* & $91.7 *$ \\
\hline & $\begin{array}{l}\text { Comply with the } \\
\text { traffic law }\end{array}$ & $80.6 *$ & 94.3* & $87.9 *$ & 76.5 & 80.4* & 78.8 & $85.0 *$ & $95.1 *$ & $90.1 *$ & $90.2 *$ & 93.2* & $91.8 *$ & 78.6 & $95.3^{*}$ & $87.1 *$ \\
\hline & Vigilant & 75.0 & $91.2 *$ & 83.3 & 64.7 & 89.1* & 78.8 & 72.5 & $95.1 *$ & 84.0 & $80.5 *$ & $88.6 *$ & 84.7 & $83.3 *$ & $95.3^{*}$ & $89.4 *$ \\
\hline \multirow{4}{*}{$\begin{array}{l}\text { Lack of } \\
\text { self } \\
\text { control }\end{array}$} & Calm & 67.6 & 88.6* & 78.3 & 44.1 & 80.4* & 65.0 & 55.0 & $80.5 *$ & 67.9 & 61.0 & 84.1* & 72.9 & 73.8 & 74.4 & 74.1 \\
\hline & Civic & 75.8 & 84.8* & 80.3 & 67.6 & 89.1* & 80.0 & $82.5 *$ & $87.8 *$ & $85.2 *$ & $80.5 *$ & $90.9 *$ & $85.9 *$ & 81.0* & $88.4^{*}$ & 84.7 \\
\hline & Disrespectful & 21.2 & 20.0 & 20.6 & 20.6 & 6.5 & 12.5 & 15.0 & 7.3 & 11.1 & 12.5 & 2.3 & 7.1 & 22.0 & 9.3 & 15.5 \\
\hline & Impatient & 56.3 & 25.7 & 40.3 & 52.9 & 41.3 & 46.3 & 40.0 & 26.8 & 33.3 & 34.1 & 38.6 & 36.5 & 45.2 & 34.9 & 40.0 \\
\hline
\end{tabular}

67 Note. * Frequencies non-different from $100(p<.05)$ according to the Dmax Kolmogorov-Smirnov Test 


\section{Discussion}

\subsection{SR associated with men and women drivers}

This study aimed at analyzing the specific content of the social representations of "the man and woman behind the wheel", specifying their different modalities of social anchoring (i.e., the social regulations in line with their social insertions). The results showed that these social representations are each organized around three principles (i.e., Factors) whose content varies according to the target. A contrast can be noted between the organizing principles regulating these two SR: women are seen as incompetent, cautious and lacking of self-control, while men are seen as competent, reckless and self-controlled.

These findings are consistent with some studies which have shown that adolescents and preadolescents already differentiate expertise and driving skills according to the driver's sex: women have abilities for safety but not for driving, while men have driving skills but neglect safety (Granié \& Pappafava, 2011). As Näätänen and Summala (1976) showed that the tendency to drive fast and to overtake is considered as an indicator of competence, the results of the present study could thus be interpreted by the following relationships: since women are incompetent they must be cautious, and because men are competent they can take risks at the wheel (Granié \& Pappafava, 2011). These representations of men and women drivers go in line with previous research (Tafani, Haguel, \& Ménager, 2007), showing that, to define their social representation of a "good car", women give more attention than men to safety, reliability and robustness, whereas men give greater attention to the engine power and hedonism. Thus, the results of the present study are in line with other findings suggesting that perceivers tend to differentiate driving skills and safety skills (Lajunen \& Summala, 1995), where the former seem to be considered as masculine skills and the latter as feminine ones. This content appears to be internalized in an essentialist way by perceivers (Heyman \& Giles, 2006; Prentice \& Miller, 2006), as driving skills seem to be described as inherent to the individual's sex group, suggesting, on the one hand, that men are naturally good at driving, and, on the other hand, that this activity is not in adequacy with the definition or the essence of women (Granié \& Pappafava, 2011).

These findings suggest that asymmetrical attributions may be made according to the driver's sex: in case of an accident, men would be judged as not sufficiently taking into account other users while women would be judged to have demonstrated a lack of mastery of the vehicle 
(Lawrence and Richardson, 2005). Conversely, in case of good driving (or accident avoidance), women would be judged to have been cautious and vigilant towards other road users (thus avoiding an accident) while men would be judged as having expertise and dexterity for car driving (and this is due to those skills that they avoid an accident). This echoes the findings from Deaux $(1977,1984)$ and Deaux and Emswiller (1974) according to whom performances that are consistent with expectations are attributed to stable and internal causes (such as ability) while performances that are inconsistent with expectations are attributed to more unstable causes (such as effort or luck). Since people usually more expect men to succeed than women (which remains the case for driving), women's successes are more likely to be attributed to luck or effort, whereas men's successes are more likely to be attributed to ability (Swim \& Sanna, 1996). Conversely, since people usually more expect women to fail than men, women's failures are more likely to be attributed to a lack of ability, whereas men's failure are more likely to be attributed to a lack of effort or of luck. In this regard, Lawrence and Richardson (2005) pointed out that accidents caused by women are seen as an inability to adopt the right behavior (i.e., acts of omission; Shaver, 1985), whereas men's accidents are attributed to carelessness or risk-taking (i.e., acts of commission). This indicates that men's successes are attributed to internal factors, these factors explaining the failure for women. Note that these performance expectations and the reasons attributed to these performances are elaborated by consensus of both sexes (Deaux \& Emswiller, 1974).

\subsection{Effects of perceiver's age in the modulation and the structure of these SR}

This study has raised the fact that these SR varied according to social insertions of the individuals. In fact, these SR are anchored through a set of positional asymmetries that reflect contrasted social regulations. Regarding the social anchoring, the results emphasize the role of sex, age and SES in the modulation and the structure of the SR. Comparisons of the affirmation frequencies for beliefs related to these SR revealed significant differences according to age, sex and SES. This can be explained by the fact that central beliefs (i.e., the core of the SR) are linked to historical, sociological and ideological environments and therefore are highly related to identity and social positions. The effects of the social insertions of individuals on the structure of these SR can be observed as some elements appear as central only in certain subgroups. 
First of all, age seems to have an effect on the SR associated with men and women drivers, insofar as the differences seem to be maximized among younger age groups. These results could be an effect of the search for positive distinctiveness and of gender intensification (Hill \& Lynch, 1983) beginning at age 12, as research shows gender stereotype conformity tends to peak of in the early adolescent period and then decline over time (Berndt, 1996). Apart from the general increase in sex stereotyping in adolescence, the area of the car and driving is particularly invested by boys and participates in the construction of masculinity (Walker, Butland, \& Connell, 2000). Whatever his physical strength, the technical ability to control the performance of a motor vehicle at high speeds helps boys to demonstrate their manhood. Driving is seen by boys as an egalitarian way (regardless of their intellectual abilities, physical skills, racial or ethnic group) to be empowered as a man (Walker et al., 2000). Thus, boys' acceptance of and compliance with the image they have constructed about male drivers could explain why, even before starting to drive, the boys of 12-16 years have riskier attitudes than girls in terms of speed and not wearing a seatbelt (Mann \& Lansdown, 2009), confirming the results by Harré, Field and Kirkwood (1996) on 15-year-old adolescents.

Secondly, age appears to have less of an effect on the image of men drivers than on the image of women drivers. Indeed, the SR associated with men drivers seem to be stable and shared across age groups, whereas the SR associated with women drivers appear more mixed, heterogeneous and unstable with age. The stability of the representation of men drivers can be seen on the components of the central core of the SR. The elements concerning the confidence and the fast driving of the male drivers are present in the central core of the SR in all age groups, from 12 to 50 and more. On the other side, the careful and civic elements of the SR of women drivers only appear in the central core of the SR from the group aged 19 to 29, these elements being central only for women in lower age groups. Furthermore, the compliance with rules is a part of the central core of the SR in the group aged 12-15 and after 19 but do not belong to the central core among the 16-18. Thus, based on the different elements, our results suggest that the SR of men drivers is stable across age groups, whereas the SR of the female drivers is more unstable with age. This could be linked to the fact that the car, as well as activities associated with (washing it, repairing it, and of course driving it), are part of the "male sex role". The child indeed early learns knowledge about gender roles and, from $21 / 2$ years of age (or even from 18 months among girls; Serbin et al., 2001), associates cars to the boys and dolls to the girls (Kuhn, Nash, \& Brucken, 1978). More generally, children have correct knowledge about gender typed activities for adults (including the car) before the end of kindergarten (Serbin, Powlishta, \& Gulko, 1993). Thus, very early on, children of both 
sexes associate the area of the car to men. The stability of the SR of the man behind the wheel, already shown among school students from 11 years old (Granié \& Pappafava, 2011), may be due to the fact that the man at the wheel serves as a normative reference for driver (Dontsov \& Kabalevskaya, 2013), from which is defined, by differentiation and opposition, the typical behavior of women drivers, more ambivalent and heterogeneous due to the different identity issues for men and women.

\subsection{Effects of perceiver's sex in the modulation and the structure of these SR}

The results show differences depending on the perceiver's sex concerning characteristics associated with drivers of each sex. Male participants, more than female ones, rated men drivers as having self-control and women drivers as lacking self-control. In contrast, female participants, more than male ones, perceived men drivers as careless and women drivers as

prudent. These results are in keeping with research on intergroup relations, which have shown how individuals seek positive distinctiveness, by denigrating the out-group while promoting the in-group (Allen \& Wilder, 1975; Brewer \& Silver, 1978; Tajfel \& Turner, 1986). Thus, one can conclude to in-group favoritism bias (Tajfel, Billig, Bundy, \& Flament, 1971) where participants promoted their in-group, by attributing higher positive and fewer negative characteristics to the drivers of their own sex group, and denigrated the out-group, by attributing fewer positive and higher negative characteristics to the drivers of the other sex group. The analysis of the central core also showed that its components were affected by participants' sex. Some positive characteristics of women drivers were only included in the core of female participants (i.e., calm, mastery of the vehicle), but this phenomenon did not occur for men drivers with male respondents. Thus, it seems that females tend to promote their sex group, more than men do. Power-based gender stereotype approaches (Zemore, Fiske, \& Kim, 2000) and the effects of social asymmetry between the sexes (Hurtig, Kail, \& Rouch, 2002) can provide an understanding of these results among females. Thus, research has shown that the dominant position of the male group (Lorenzi-Cioldi, 1988a, 1988b; Sidanius, Pratto, \& Rabinowitz, 1994) leads members of the socially dominated female group to over-promote the in-group (Powlishta, 1995; Rudman \& Goodwin, 2004; Serbin et al., 1993). The emergence of some added positive characteristics of women drivers may be used by the female participants to reverse the negative stereotype according to which they would be poor drivers. It appears that associating the driving activity with the male role in society causes females to "defend" their gender identity more than males need to. 
But despite this in-group promotion among females, men's driving skills were considered relatively important, and reflected a consensus between men and women (i.e., no effects of perceiver's sex on the whole sample), whereas women's incompetence was considered relatively medium in a general way and was more pronounced among men. In fact, male seem to believe (at least more than females) that women are not very competent for driving, whereas both groups seem to agree on men good driving skills. Thus, it appears the SR elaborated by the members of the male dominant group concerning the members of the female subordinate group enables the former to legitimize their dominant position. But at the same time, the SR elaborated by the members of the female subordinate group concerning the members of the male dominant group allows the former to justify their position of subordination. In this sense, developing and sharing a negative representation on women drivers allows the male group to justify their dominant position in road space. Otherwise, according to Fiske (1993), the stereotypical judgment is a way of exercising control over others, which reinforces the power of an individual or a group. In other words, stereotypes are used by members of dominant groups to maintain the status quo (Vescio, Gervais, Heiphetz, \& Bloodhart, 2009). This can be related to the work of Berger (1986), according to which negative stereotypes about women drivers were spread in the early twentieth century due to the men's fear of women's emancipation that could be generated by the car. As a result, this fear would have been at the base of a negative stereotype toward women drivers, in order to minimize the impact of the automobile as a perspective of women's liberation and involvement into social change. Various popular beliefs against their driving style appeared, that would make them poor drivers. Otherwise, from a normative viewpoint, one can hypothesize that the propagation of the negative representation of the woman behind the wheel as well as the masculine qualification of this practice has formed a norm according to which women are not made for driving. Consequently, when women fail, it confirms the commonly-held negative representation, but when they success, they threat the established order and they are qualified as exceptions: this kind of woman is made masculine (i.e., tomboy). In fact this widespread negative representation constitutes a way for normalizing the behaviors and aims at maintaining the social order. Concerning the effect of sex, this research also illustrated the central role of intergroup differentiation in SR. This reflects that the topic of the questionnaires emphasizes sex differences, which challenged social identity. Intergroup differentiation is more salient when participants are focused on intergroup comparison and when social identity is threatened (Jetten, Brandscombe, \& Spears, 2002; Jetten, Spears \& 
Manstead, 1997). This can explain why women consider more than men that men are careless at the wheel and why women consider less than men that women do not have driving skills.

\subsection{Effects of perceiver's SES in the modulation and the structure of these SR}

The results show that the SES also impacts the SR on women driving. Indeed, participants with higher SES consider female drivers as more incompetent, more nervous and less cautious than participants with lower SES. Besides, the results showed that differences between men and women seem to vary according the participant's SES. Female's responses tend indeed to be closer to those provided by the male group when they are higher SES. This was the case for the positive elements associated with their group (e.g., prudence): higher SES women depreciated more their group than lower SES, their responses being thus more similar to those of men. This was also the case for the negative elements associated with their group (e.g., incompetence) where the same phenomenon seemed to occur: higher SES women were more likely to devalue their group. Concerning elements associated with men, lower SES women promoted more men than higher SES women (and even more than men did). Again in this case, higher SES women's responses are more similar to those of men as if, for women with higher SES, socioeconomic status was favored over the membership of the gender group, the first leading to a dominant and valued position than the second does not bring. By devaluing their gender group, higher SES women may emphasize their dominance linked to their socioeconomic status and thus get closer to the position of men. In a perspective of social dominance (Sidanius \& Pratto, 1999), this reflects the depreciation conducted by the dominant group (i.e., women with higher SES) to maintain the asymmetry with the dominated group (i.e., women with lower SES). As previously discussed, this phenomenon seems to take place at a larger level, between the male and female groups, in the same perspective of maintaining the status quo.

\subsection{Practical consequences from a traffic perspective}

The practical significance of these results obviously concerns the sex differences in crashes and driving behaviors. In addition to biological sex differences, differences in observable risktaking between men and women in road space are due to the manifestation of a behavior consistent with social expectations (Ronay \& Kim, 2006). Expectations, as the results showed, are also observed in the gender stereotypes associated with driving, and socially 
interpreted as due to innate differences between sexes toward risk-taking and driving (Granié \& Pappafava, 2011). As a result, the level of individual compliance with masculine stereotypes has a direct effect of increased risk-taking (Özkan \& Lajunen, 2006), as taking risk is a behavior involved in the social definition of masculinity (Green, 1997; Green \& Hart, 1998; Papadakis \& Moore, 1991; Walker et al., 2000). The level of individual compliance with feminine stereotypes also plays an indirect role in causing a higher level of traffic rules internalization that inhibits taking risks (Granié, 2009). More specifically, the differentiated beliefs about the driving abilities of men and women could have direct implications on men and women behaviors and may cause effect of stereotype threat on women drivers. Previous studies (Chateignier et al., 2011; Félonneau \& Becker, 2011; Yeung \& von Hippel, 2008) thus provide evidence that risk-taking is under the influence of gender identity, specifically the mobilization of individuals belonging to a social sex group and of behaviors allowing the individual to demonstrate this social identity. These beliefs could explain why, even before they start driving, the boys have riskier attitudes than girls in terms of speed and not wearing a seatbelt (Harré et al., 1996; Mann \& Lansdown, 2009) and why girls' and boys' attitudes toward driver training differ, with boys feeling more competent as driver than girls, even before they start learning to drive (Nyberg \& Gregersen, 2007; Wiberg, 2006).

\section{Conclusion}

The objectives of this study were to analyze the specific content of the social representations of "the man and woman behind the wheel" and to specify their different modalities of social anchoring examining the effect of social insertions on these social representations. The results showed that these SR of men and women drivers are organized around three main principles (or dimensions): carelessness, driving skills and self-control concerning men and incompetence, prudence and lack of self-control among women drivers. Some characteristics emerge as central in most age groups about man (confidence, fastness and pleasure of driving) and women (caution, civility, compliance with rules and vigilance) drivers. Analysis of the structure of these SR showed its variation according to the social anchoring variables. Thus, the SR of the man driver appears to be stable and homogeneous through age groups, whereas the SR of the woman driver is more heterogeneous and differentiated according to the age group of the participants. In addition, even if each individual tends to overvalue, especially among females, their own sex group and devalue the other sex group, both sex groups seem to 
agree on men good driving skills and participants with higher SES tend to have a more negative representation of women drivers than participants with lower SES.

These results can, thus, be used as a basis for more detailed research on the effect of these beliefs in individuals' driving behavior and on socialization to risk-taking. The results show that differentiated social representations of the driver according to the driver's sex group do indeed exist and can be detected in individuals' discourses from adolescence and across age groups. These social representations of men and women drivers are the expression of more general sex stereotypes: female compliance and male risk-taking. Furthermore, they expose an essentialist view of sex roles. Thus, the social promotion of an activity for a certain group of individuals, here men, can bring individuals to interpret the underlying abilities as naturally present in the individuals of this group and to consider individuals of the other group as being naturally unfit. These results could thus be explained by the acceptance of and compliance with the image individuals of both sexes have constructed about male and female drivers in a culture where seeking out risk through driving is part of the manliness construction (Hopkins \& Emler, 1990). Lastly, the results of this study show that the representation of male and female drivers - and maybe the behaviors related to it - appears to be a field of expression of personal and social identity and thus is involved in the social differentiation (Green, 1997; Green \& Hart, 1998; Papadakis \& Moore, 1991; Walker et al., 2000).

\section{References}

Abric, J. C. (1993). Central system, peripheral system: their function and roles in the dynamic of social representations, Papers on Social Representations, 2, 75-78

Abric, J. C. (2001). A structural approach to social representations. In K. Deaux \& G.

Philogène (Eds.), Representations of the social: Bridging theoretical traditions (pp. 42-47). Malden, MA: Blackwell Publishing.

Abric, J. C. (2003). Méthodes d'étude des représentations sociales [Methods for studying social representations] (pp. 59-80). Ramonville Saint-Agne, France: Erès.

Allen, V. L., \& Wilder, D. A. (1975). Categorization, belief similarity, and intergroup discrimination. Journal of Personality and Social Psychology, 32,971-917.

Assailly, J. P. (2005). Revue de questions sur le continuum éducatif [Litterature review on the educational continuum in road safety education]. Arcueil: INSERR-INRETS 
Berger, M. L. (1986). Women drivers!: The emergence of folklore and stereotypic opinions concerning feminine automotive behavior. Women's Studies International Forum, 9(3), 257263. doi:10.1016/0277-5395(86)90061-0.

Berndt, T.J. (1996). Transitions in friendship and friends' influence. In J.A. Graber, J. BrooksGunn, \& A.C. Petersen (Eds.), Transitions through adolescence: Interpersonal domains and context (pp. 57-84). Mahwah, NJ: Erlbaum.

Bourdieu, P. (1990). The logic of practice. San Francisco, SF: Stanford University Press (original french publication in 1980)

Brewer, M. B., \& Silver, M. (1978). Ingroup bias as a function of task characteristics.

European Journal of Social Psychology, 8, 393-400.

Chateignier, C., Chekroun, P., Nugier, A., \& Dutrévis, M., (2011). «Femme au volant. . »: effet de la menace du stéréotype et de la colère sur les performances des femmes à une tâche liée à la conduite automobile ["Woman at the wheel ...": effect of stereotype threat and anger on the performance of women in a task related to car driving]. L'Année psychologique [Topics in Cognitive Psychology], 111(4), 673-700.

Dafflon, A. C. (1999). Perception d'homogénéité dans les groupes. Effet des positions statutaires respectives des groupes [Perception of homogeneity in groups. Effect of the respective statutory positions of the groups]. In J. L. Beauvois, N. Dubois \& W. Doise (Eds.), La construction sociale de la personne [The social construction of the person] (pp. 147-155). Grenoble: Presses Universitaires de Grenoble.

Dany, L., Urdapilleta, I., \& Lo Monaco, G. (2015). Free associations and social representations: some reflections on rank-frequency and importance-frequency method. Quality \& Quantity, 49(2), 489-506.

Davies, G. M., \& Patel, D. (2005). The influence of car and driver stereotypes on attributions of vehicle speed, position on the road and culpability in a road accident scenario. Legal and Criminological Psychology, 10, 45-62.

Deaux, K. (1977). Social psychology of sex roles. In L. S. Wrightsman (Ed.), Social psychology (2nd ed.). Monterey, CA: Brooks/Cole.

Deaux, K. (1984). From individual differences to social categories: Analysis of a decade's research on gender. American Psychologist, 39, 105-116.

Deaux, K., \& Emswiller, T. (1974). Explanations of successful performance on sex-linked task what is skill for male is luck for the female, Journal of Personality and social psychology, 29, $80-85$.

Derks, B., Scheepers, D., Laar, C. V., \& Ellemers, N. (2011). The threat vs. challenge of car parking for women: How self- and group affirmation affect cardiovascular responses. Journal of Experimental Social Psychology, 47, 178-183. 
Desrosières , A., \& Thévenot, L. (2012). Les catégories socio-professionnelles [The socioprofessional categories]. Paris: La Découverte.

Doise, W. (1986). Les représentations sociales. Définition d'un concept [The social representations. Definition of a concept]. In W. Doise et A. Palmonari (Eds.), L'étude des représentations sociales [The study of the social representations] (pp. 81-94). Neuchâtel: Delachaux \& Niestlé.

Doise, W. (1990). Les représentations sociales [The social representations]. In R. Ghiglione, C. Bonnet et J.-F. Richard (Eds.), Traité de psychologie cognitive. Cognition, représentation, communication [Handbook of cognitive psychology. Cognition, representation, communication] (pp. 111-174). Paris: Dunod.

Doise, W. (1993). Debating social representations. In: G. M. Breakwell, D. V. Canter (Eds.), Empirical Approaches to Social Representations (pp. 157-170). Oxford: Clarendon Press. Doise, W., Clémence, A. \& Lorenzi-Cioldi, F. (1993). The Quantitative analysis of social representations. London: Harvester Wheatsheaf.

Dontsov, A.I., Kabalevskaya, A.I. (2013). Gender stereotypes among road users. Psychology in Russia. State of the Art, 6 (3), 150-163.

Evans, L. (1991). Traffic Safety and the Driver. New-York: Van-Nostrand Reinhold. Fabrigar, L. R., Wegener, D. T., MacCallum, R. C., \& Strahan, E. J. (1999). Evaluating the use of exploratory factor analysis in psychological research. Psychological Methods, 4, $272-$ 299.

Felonneau, M. L., \& Becker, M. (2011). "Femmes au volant, danger au tournant”. Les conductrices sont-elles victimes d'une menace de stéréotype ? [Women at the wheel, danger round the bend. Are female drivers victim of a stereotype threat?] Psychologie du Travail et des Organisations [Psychology of Work and Organizations], numéro 2 spécial « Genre et Travail », 17(4), 314-329.

Flament, C. (1995). Approche expérimentale de type psychophysique dans l'étude d'une représentation [Psychophysical experimental approach in the study of a representation]. Les Cahiers internationaux de Psychologie sociale [International Letters in Social Psychology], 28, 67-76.

Flament, C. (1996). Les valeurs du travail : la psychologie des représentations sociales comme observatoire d'un changement historique [The values of work: the psychology of social representations as an observatory of historical change]. In J.C. Abric (Ed.), Exclusion sociale, insertion et prévention [Social exclusion, insertion and prevention] (pp. 113-124). Ramonville Saint-Agne: Eres.

Fiske, S. T. (1993). Controlling other people: The impact of power on stereotyping. American Psychologist, 48, 621-628. 
Gaymard, S. (2006). The representation of old people: comparison between the professionals and students. International Review of Social Psychology, 19(3-4), 69-92.

Granié, M. A. (2009). Effects of gender, sex-stereotype conformity, age and internalization on risk-taking among adolescent pedestrians. Safety Science, 47(9), 1277-1283.

Granié, M. A., \& Papafava, E. (2011). Gender stereotypes associated with vehicle driving among French preadolescents and adolescents. Transportation Research Part F: Traffic Psychology and Behaviour, 14(5), 341-353. doi:10.1016/j.trf.2011.04.002

Green, J. (1997). Risk and the construction of social identity: children's talk about accidents. Sociology of Health \& Illness, 19(4), 457-479.

Green, J., \& Hart, L. (1998). Children's views of accident risks and prevention: a qualitative study. Injury Prevention, 4, 14-21.

Hanna, C. L., Taylor, D. M., Sheppard, M. A., \& Laflamme, L. (2006). Fatal crashes involving young unlicensed drivers in the U.S. Journal of Safety Research, 37(4), 385-393.

doi:10.1016/j.jsr.2006.05.007

Harré, N., Field, J., Kirkwood, B. (1996). Gender differences and areas of common concern in the driving behaviors and attitudes of adolescents. Journal of Safety Research, 27(3), 163-173. Heyman, G. D., \& Giles, J. W. (2006). Gender and Psychological Essentialism. Enfance; psychologie, pedagogie, neuropsychiatrie, sociologie, 58(3), 293-310.

Hill, J.P., Lynch, M.E. (1983). The intensification of gender-related role expectations during early adolescence. In Brooks-Gunn, J. \& Petersen, A.C. (Eds.), Girls at puberty: Biological and psychosocial perspectives (pp. 201-228). New-York, NY: Plenum.

Hopkins, N., \& Emler, N. (1990). Social network participation and problem behavior in adolescence. In K. Hurrelman and F. Lösel (Eds.), Health hazards in adolescence (pp. 385407). Berlin: de Gruyter.

Hurtig, M. C., Kail, M. \& Rouch, H. (2002). Sexe et Genre. De la hiérarchie entre les Sexes [Sex and Gender. The hierarchy between the sexes]. Paris: CNRS éditions.

Jetten, J., Branscombe, N.R., \& Spears, R. (2002). On being peripheral: Effects of identity insecurity on personal and collective self-esteem. European Journal of Social Psychology, 32, 105-123.

Jetten, J., Spears, R., \& Manstead, A.S.R. (1997). Distinctiveness threat and prototypicality: Combined effects on intergroup discrimination and collective self- esteem. European Journal of Social Psychology, 27, 635-657.

Kaiser, H.F. (1960). The application of electronic computers to factor analysis. Educational and Psychological Measurement, 20, 141-151.

Kanji, G. K. (2006). 100 Statistical Tests. London: Sage Publications.

Kuhn, D., Nash, S.C., \& Brucken, L. (1978). Sex role concepts of two- and three-year-olds. Child Development, 49, 445-451. 
Lajunen, T., \& Summala, H. (1995). Driver experience, personality, and skill and safety motive dimensions in drivers' self-assessments. Personality and Individual Differences, 19, $307-318$.

Lawrence, C., \& Richardson, J. (2005). Gender-Based Judgments of Traffic Violations: The Moderating Influence of Car Type1. Journal of Applied Social Psychology, 35(8), 1755-1773. doi:10.1111/j.1559-1816.2005.tb02194.x

Lo Monaco, G., \& Guimelli, C. (2011). Hegemonic and polemical beliefs: Culture and consumption in the social representation of wine. The Spanish Journal of Psychology, 14(1), 232-245. http://dx.doi.org/10.5209/rev_SJOP.2011.v14.n1.21

Lo Monaco, G., Lheureux, F., \& Halimi-Falkowicz, S. (2008). Test d'Indépendance au Contexte (TIC) et Structure des Représentations Sociales [Test of Context Independence (TCI) and Structure of Social Representations]. Swiss Journal of Psychology, 67(2), 119-123. http://dx.doi.org/10.1024/1421- 0185.67.2.119 Lo Monaco, G., Piermattéo, A, Guimelli, C., \& Abric, J. C. (2012). Questionnaire of characterization and correspondence factor analysis: a methodological contribution in the field of social representations. The Spanish Journal of Psychology, 15(3), 1233-1243.

Lorenzi-Cioldi, F. (1988a). Discriminations entre soi et autrui et catégorisation sociale [Discrimination between self and other and social categorization]. International Review of Social Psychology /Revue Internationale de Psychologie Sociale, 1(2), 239-256.

Lorenzi-Cioldi, F. (1988b). Individus dominants et groupes dominés. Images masculines et féminines [Dominant individuals and dominated groups. Masculine and feminine images]. Grenoble: Presses Universitaires de Grenoble.

Lorenzi-Cioldi, F. (1997). Professions au masculin et au féminin : un moyen terme entre le masculin et le féminin [Male and female professions: a middle ground between the masculine and the feminine]. International Review of Social Psychology/Revue Internationale de Psychologie Sociale, 10(2), 135-152.

Mann, H.N., \& Lansdown, T. (2009). Pre-driving adolescent attitudes: Can they change? Transportation Research Part F: Traffic Psychology and Behaviour, 12, 395-403.

Moliner, P. (1995). A two dimensional model of social representations. European Journal of Social Psychology, 1, 27-40.

Moliner, P. (2002). Ambiguous scenario and attribute challenge techniques. Social Representations of "The Firm" and "The nurse". European Revue of Applied Psychology, 52(3-4), 273-280.

Moliner, P., \& Tafani, E. (1997). Attitudes and social representations: a theorical and experimental approach. European Journal of Social Psychology, 27, 687-702. 
Moliner, P., Rateau, P., \& Cohen-Scali, V. (2002). Les Représentations sociales: Pratique des études de terrain [Social Representations: Practice of field studies]. Rennes: Presses universitaires de Rennes.

Moscovici, S. (1988). Notes towards a description of social representations. European Journal of Social Psychology, 18(3), 211-250. doi:10.1002/ejsp.2420180303

Moscovici, S. (2008). Psychoanalysis: Its Image and Its Public. Cambridge, United Kingdom: Polity Press (original French editions 1961, 1976).

Mouret, M., Lo Monaco, G., Urdapilleta, I., \& Parr, W.V. (2013). Social representations of wine and culture: a comparison between France and New Zealand. Food Quality and Preference, 30(2), 102-107.

Näätänen, R., \& Summala, H. (1976). Road user behavior and traffic accidents. Amsterdam/New York: North-Holland/American Elsevier.

Nell, V. (2002). Why Young Men Drive Dangerously? Implications for Injury Prevention. Current Directions in Psychological Science, 11(2), 75-79. doi:10.1111/1467-8721.00172 Nyberg, A., \& Gregersen, N. P. (2007). Practicing for and performance on drivers license tests in relation to gender differences in crash involvement among novice drivers. Journal of Safety Research, 38, 71-80.

Özkan, T., \& Lajunen, T. (2005). Why are there sex differences in risky driving? the relationship between sex and gender-role on aggressive driving, traffic offences, and accident involvement among young turkish drivers. Aggressive Behavior, 31(6), 547-558.

doi:10.1002/ab.20062

Özkan, T., \& Lajunen, T. (2006). What causes the differences in driving between young men and women? The effects of gender roles and sex on young drivers' driving behaviour and selfassessment of skills. Transportation Research Part F: Traffic Psychology and Behaviour, 9(4), 269-277. doi:10.1016/j.trf.2006.01.005

Papadakis, E., Moore, A. (1991). Drink-driving and adolescent lifestyles: Rethinking policy. Australian Journal of Social Issues, 25, 83-106.

Pianelli, C., Abric, J.-C., \& Saad, F. (2010). Rôle des représentations sociales préexistantes dans les processus d'ancrage et de structuration d'une nouvelle représentation [Role of existing social representations in the process of anchoring and structuring a new representation]. Cahiers Internationaux de Psychologie Sociale [International letters Social Psychology], 86, 241-274.

Powlishta, K. K. (1995). Intergroup processes in childhood: Social categorization and sex role development, 31, 781-788.

Prentice, D. A., \& Miller, D. T. (2006). Essentializing Differences Between Women and Men. Psychological Science, 17(2), 129-135. doi:10.1111/j.1467-9280.2006.01675.x 
Rateau, P. (2004). Psychosociological anchoring and structural dynamic of social representations of the heterosexual/homosexual couple. Swiss Journal of Psychology, 63, 4251.

Rateau, P., Moliner, P., Guimelli, C. \& Abric, J.C. (2011). Social Representation Theory. In P.A.M. Van Lange, A.W. Kruglanski \& E.T. Higgins (Eds.), Handbook of Theories of Social Psychology, Vol. 2, (pp. 477-407). Los Angeles / London: Sage Publications.

Ronay, R., \& Kim, D.-Y. (2006). Gender Differences in Explicit and Implicit Risk Attitudes: A socially Facilitated Phenomenon. British Journal of Social Psychology, 45(2), 397-419. Rudman, L. A., \& Goodwin, S. A. (2004). Gender differences in automatic in-group bias: Why do women like women more than men like men? Journal of Personality and Social Psychology, 87, 494-509.

Serbin, L.A., Poulin-Dubois, D., Colburne, K.A., Sen, M.G., \& Eichstedt, J.A. (2001). Gender stereotyping in infancy: Visual preferences for and knowledge of gender-stereotyped toys in the second year. International Journal of Behavioral Development, 25(1), 7-15.

Serbin, S. A., Powlishta, K. K., \& Gulko, J. (1993). The development of sex typing in middle childhood. Monographs of the Society for Research in Child Development, 58(2), 1-99.

Shaver, K. G. (1985). The attribution of blame: Causality, responsibility, and blameworthiness. New-York, NY: Springer-Verlag.

Sidanius, J., \& Pratto, F. (1999). Social dominance: an intergroup theory of social hierarchy and oppression. New York, NY: Cambridge University Press.

Sidanius, J., Pratto, F., \& Rabinowitz, J. L. (1994). Gender, ethnic status, and ideological asymmetry: A social dominance interpretation. Journal of Cross-Cultural Psychology, 25, 194-216.

Slovic, P., Flynn, J., \& Layman, M. (1991). Perceived risk, trust, and the politics of nuclear waste. Science, 254, 1603-1607.

Steele, C. M., \& Aronson, J. (1995). Stereotype threat and the intellectual test performance of African Americans. Journal of Personality and Social Psychology, 69(5), 797-811. doi:10.1037/0022-3514.69.5.797

Swim, J. K., \& Sanna, L. J. (1996). He's skilled, she's lucky: A meta-analysis of observers' attributions for women's and men's successes and failures. Personality and Social Psychology Bulletin, 22(5), 507-519.

Tafani, E., \& Bellon, S. (2001). Principe d'homologie structurale et dynamique représentationnelle [Structural homology principle and representational dynamic]. In P. Moliner (Ed.), La dynamique des représentations sociales [The dynamics of social representations] (pp. 163-193). Grenoble: Presses Universitaires de Grenoble.

Tafani, E., Bellon, S., \& Apostolidis, T. (2002), Théorie des champs sociaux et dynamique représentationnelle: Études des effets des asymétries positionnelles sur la structure d'une 
représentation sociale [Theory of social fields and representational dynamic: Studies of the effects of positional asymmetries on the structure of a social representation]. International Review of Social Psychology /Revue Internationale de Psychologie Sociale, 15(2), 57-90. Tafani, E., Haguel, V., \& Menager, A. (2007). Des images de marque aux représentations sociales des marques : Une application au secteur de l'automobile [From brand images to social representations of brands: An application to the automobile sector]. Les Cahiers Internationaux de Psychologie Sociale [International Letters in Social Psychology], 73, 27-46. Tajfel, H., Billing, M., Bundy, R., \& Flament, C. (1971). Social categorization and intergroup behaviour. European Journal of Social Psychology, 1, 149-177.

Tajfel, H., \& Turner, J. C. (1986). The social identity theory in intergroup behavior. In S. Worchel \& W. G. Austin (Eds.), Psychology of intergroup relations ( $2^{\text {nd }}$ ed., pp. 7-24). Chicago: Nelson-Hall.

Taubman-Ben-Ari, O., Mikulincer, M., \& Gillath, O. (2004). The multidimensional driving style inventory - Scale construct and validation. Accident Analysis and Prevention, 36, 323332.

Vescio, T. K., Gervais, S. J., Heiphetz, L., \& Bloodhart, B. (2009). The stereotypic behaviors of the powerful and their effect on the relatively powerless. In T. Nelson (Ed.), The handbook of prejudice, stereotyping, and discrimination (pp. 247-266). New York, NY: Psychology Press.

Viaud, J. (2000). Principes organisateurs et représentations sociales de l'économie : genèse et dynamique [Organizing principles and social representations of the economy: genesis and dynamic]. International Review of Social Psychology/Revue Internationale de Psychologie Sociale, 12(2), 79-105.

Wagner, W., Valencia, J., \& Elejabarrieta, F. (1996). Relevance, discourse and the 'hot' stable core of social representations: a structural analysis of word associations. British Journal of Social Psychology, 35(3), 331-351.

Walker, L., Butland, D., Connell, R.W. (2000). Boys on the road: masculinities, car culture, and road safety education. The Journal of Men Studies, 8(2), 153-169.

Wiberg, M. (2006). Gender differences in the Swedish driving-license test. Journal of Safety Research, 37, 285-291.

Yagil, D. (1998). Gender and age-related differences in attitudes toward traffic laws and traffic violations. Transportation Research Part F: Traffic Psychology and Behaviour, 1(2), 123-135. doi:10.1016/S1369-8478(98)00010-2

Yeung, N. C. J., \& von Hippel, C. (2008). Stereotype threat increases the likelihood that female drivers in a simulator run over jaywalkers. Accident Analysis \& Prevention, 40(2), 667-674. doi:10.1016/j.aap.2007.09.003 
Zemore, S. E., Fiske, S. T., \& Kim, H.-J. (2000). Gender stereotypes and the dynamics of social interaction. In T. Eckes \& H. M. Trautner (Eds.), The developmental social psychology of gender (pp. 207-241). London: Lawrence Erlbaum Associates. 


\section{Appendix A}

\begin{tabular}{|c|c|c|c|c|c|}
\hline $\begin{array}{l}\text { Categories } \\
\text { (Men drivers) }\end{array}$ & Characteristics & Frequency & $\begin{array}{l}\text { Categories } \\
\text { (Women } \\
\text { drivers) }\end{array}$ & Characteristics & Frequency \\
\hline Disrespectful & $\begin{array}{l}\text { Aggressive, angry, rude, vulgar, grumpy, } \\
\text { intolerant, incivility, discourteous, selfish, } \\
\text { individualistic, self-centered }\end{array}$ & $N=199$ & Careful, cautious & Cautious, prudent, reassuring, protective, less risk & $N=160$ \\
\hline Impatient & $\begin{array}{l}\text { Impatient, hurry, brutal conduct, nervous, } \\
\text { impulsive, stressed, horn }\end{array}$ & $N=142$ & Dangerous & $\begin{array}{l}\text { Reckless, dangerous, imminent death, unconscious, } \\
\text { accident }\end{array}$ & $N=139$ \\
\hline Fast & Drive fast, speed & $N=107$ & Inattentive & $\begin{array}{l}\text { Low concentration, distracted, makeup while } \\
\text { driving, doing two things at the same time }\end{array}$ & $N=93$ \\
\hline Dangerous & $\begin{array}{l}\text { Reckless, dangerous, carelessness } \\
\text { unconscious, accidents, road hog }\end{array}$ & $N=106$ & $\begin{array}{l}\text { Lack of technical } \\
\text { skills }\end{array}$ & $\begin{array}{l}\text { Difficulties for maneuvering, understands nothing in } \\
\text { mechanics, does not know their way, difficulties to park }\end{array}$ & $N=70$ \\
\hline $\begin{array}{l}\text { Do not comply with } \\
\text { the traffic law }\end{array}$ & $\begin{array}{l}\text { Noncompliance with the highway code, } \\
\text { irresponsible, alcohol, drug, offenses, } \\
\text { transgression of the rules }\end{array}$ & $N=76$ & Slow & Drive slowly, drives like a granny, traffic jam & $N=68$ \\
\hline Manly & $\begin{array}{l}\text { Virility, domination, sense of superiority, } \\
\text { power, macho, sexist }\end{array}$ & $N=72$ & Clumsy & $\begin{array}{l}\text { Lack of practical skills, lack of mastery, } \\
\text { poor reflexes, clumsy, poor conductor, bad driver }\end{array}$ & $N=59$ \\
\hline Show-off & Arrogant, flirt, proud, conceited & $N=62$ & $\begin{array}{l}\text { Comply with the } \\
\text { traffic law }\end{array}$ & $\begin{array}{l}\text { Compliance with limitations, compliance with highway } \\
\text { code, compliance with traffic signals, responsible }\end{array}$ & $N=52$ \\
\hline $\begin{array}{l}\text { Dexterous, } \\
\text { Good driver }\end{array}$ & $\begin{array}{l}\text { Practical skills, mastery of vehicle, } \\
\text { control, reflexes, pilot, performance. }\end{array}$ & $N=47$ & Vigilant & Attentive, focused, alert & $N=49$ \\
\hline Careful, cautious & $\begin{array}{l}\text { Prudent, security, responsible, attentive, } \\
\text { focused, alert }\end{array}$ & $N=41$ & Civic & Respectful, courteous, cordial, citizenship, polite, kind & $N=47$ \\
\hline Confident & Confidence, self-confidence & $N=40$ & $\begin{array}{l}\text { Lack of } \\
\text { confidence }\end{array}$ & Shy, hesitant, unsure of herself, timid, anxious, panic & $N=42$ \\
\hline Pleasure of driving & $\begin{array}{l}\text { Pleasure, like driving, freedom, travel, big } \\
\text { cars, fast cars, the importance of the car, } \\
\text { attached to the vehicle }\end{array}$ & $N=28$ & Disrespectful & Rude, incivility, vulgar, aggressive, hysterical, angry & $N=40$ \\
\hline Technical skills & $\begin{array}{l}\text { Maneuvers, mechanics, sense of direction, } \\
\text { technique, good for parking }\end{array}$ & $N=23$ & Calm & Patience, calm, less impulsive & $N=40$ \\
\hline Inattentive & Inattentive, low concentration, distracted & $N=19$ & Impatient & Impatient, hurry, nervous, stressed, horn & $N=39$ \\
\hline
\end{tabular}




\section{Civic}

Incompetent

Natural facilities

Calm

\section{Gallant, cordial, citizenship, polite}

Drive poorly

Facilities, talented, natural talent, abilities, predisposed, natural expertise

Calm, serenity, patient

$\begin{array}{ll}N=14 & \begin{array}{l}\text { Transgression of } \\ \text { the rules }\end{array} \\ N=13 & \begin{array}{l}\text { Not made for } \\ \text { driving }\end{array} \\ N=12 & \begin{array}{l}\text { Mastery of the } \\ \text { vehicle }\end{array} \\ N=9 & \begin{array}{l}\text { Functional } \\ \text { aspects of the } \\ \text { driving }\end{array}\end{array}$

Noncompliance with the highway code, irresponsible, alcohol

Not made for it, "another woman at the wheel", naturally bad

Skills, mastery, control, smooth driving, good driver

Daily trips, small cars, cheaper car, sober car, practical car

$$
\begin{aligned}
& N=37 \\
& N=32 \\
& N=22 \\
& N=21
\end{aligned}
$$

